
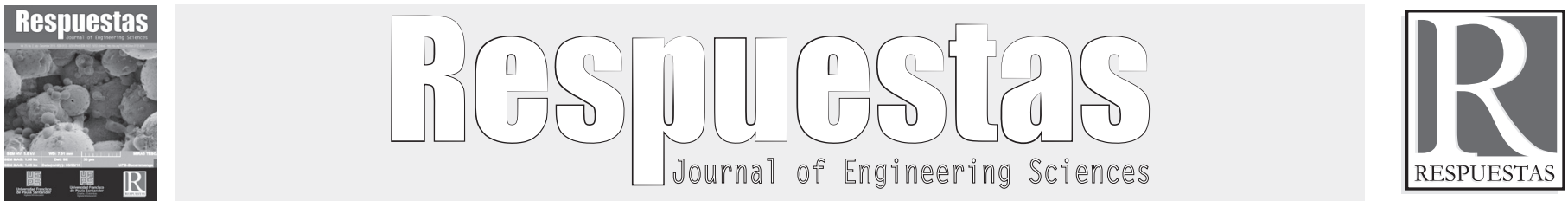

Original Article

https://doi.org/10.22463/0122820X.1726

\title{
Evaluation of the in vitro growth of the culture of oregano (Origanum vulgare) from organogenesis's technology
}

\author{
Evaluación del crecimiento in vitro del cultivo de orégano (Origanum vulgare) a partir de la técnica de \\ organogénesis \\ Heimy Jerylee Camacho-Camachoㄹ, Christian Andrei Chacín-Zambrano²*, Leydy Gabriela Rodríguez ${ }^{3}$ \\ ${ }^{I}$ Microbiólogo Industrial, hejec@hotmail.com, Orcid: 0000-0001-9693-7129, Universidad de Santander, Bucaramanga, Colombia \\ ${ }^{2 *}$ Magíster en Biotecnología Microbiana, cchacin@udes.edu.co, Orcid: 0000-0001-7241-3822, Universidad de Santander, Bucaramanga, Colombia. \\ ${ }^{3}$ Ingeniero Biotecnológica, lgrodriguez96@misena.edu.co, Orcid: 0000-0001-8926-4931, Tecnoparque Sena Nodo Bucaramanga, Bucaramanga, Colombia.
}

How to cite: H.J. Camacho-Camacho, C.A. Chacín-Zambrano and L.G. Rodríguez, "Evaluation of the in vitro growth of the culture of oregano (origanum vulgare) from organogenesis's technology”, Respuestas, vol. 23, no. 2, pp. 36-42, 2018.

Received on January 16, 2018 - Approved on May 28, 2018.

\begin{tabular}{|c|c|}
\hline & ABSTRACT \\
\hline Keywords: & There was evaluated the in vitro growth of the culture of Origanum vulgare from Organogénesis's technology. \\
\hline $\begin{array}{l}\text { Hormones of } \\
\text { vegetable growth, } \\
\text { microspread, } \\
\text { oregano }\end{array}$ & $\begin{array}{l}\text { Three treatments of disinfection were applied for the explantes, with modifications in the time of dip, etc., } \\
\text { evaluating the following variables: percentage of explantes prosperous, contaminated and oxidized. For the } \\
\text { phase of establishment and multiplication, there were evaluated five and three means of culture Murashige } \\
\text { and Skoog respectively, modifying the concentrations of the hormones. In agreement to the evaluation of } \\
\text { the treatments of disinfection, one determined that the treatment one (T1), generated } 100 \% \text { of explantes } \\
\text { prosperous, opposite to the treatments other treatments. As for the means of culture Murashige and Skoog } \\
\text { used in the phase of establishment the half number four (Ms4) possesses a significant difference in the } \\
\text { percentage of germination, opposite to other means of culture evaluated. In the stage of multiplication the } \\
\text { half number three (Mn3) with regard to the variable of height of the stem obtained a significant difference } \\
\text { in relation with other evaluated means. Finally, in the phase of establishment the way Ms } 4 \text { obtained the best } \\
\text { performance in the germination of the seeds of oregano, in the stage of multiplication of the plántulas there } \\
\text { was demonstrated a relation of } 1: 20 \text {, demonstrating a massive multiplication from a plant boss in the way of } \\
\text { culture Murashige and Skoog Mn3, vitroplantas free of pathogenic. }\end{array}$ \\
\hline
\end{tabular}

\section{RESUMEN}

\section{Palabras clave:}

Hormonas de crecimiento vegetal, micropropagación, orégano
Se evaluó el crecimiento in vitro del cultivo de Origanum vulgare a partir de la técnica de Organogénesis. Se aplicaron tres tratamientos de desinfección para los explantes, con modificaciones en el tiempo de inmersión, etc., evaluando las siguientes variables: porcentaje de explantes prósperos, contaminados y oxidados. Para la fase de establecimiento y multiplicación, se evaluaron cinco y tres medios de cultivo Murashige \& Skoog respectivamente, modificando las concentraciones de las hormonas. De acuerdo a la evaluación de los tratamientos de desinfección, se determinó que el tratamiento uno (T1), generó el 100\% de explantes prósperos, frente a los tratamientos demás tratamientos. En cuanto a los medios de cultivo Murashige \& Skoog utilizados en la fase de establecimiento el medio número cuatro (Ms4) posee una diferencia significativa en el porcentaje de germinación, frente a los demás medios de cultivo evaluados. En la etapa de multiplicación el medio número tres $(\mathrm{Mn} 3)$ respecto a la variable de altura del tallo obtuvo una diferencia significativa en relación con los demás medios evaluados. Finalmente, en la fase de establecimiento el medio Ms4 obtuvo el mejor rendimiento en la germinación de las semillas de orégano, en la etapa de multiplicación de las plántulas se evidenció una relación de 1:20, demostrando una multiplicación masiva a partir de una planta patrón en el medio de cultivo Murashige \& Skoog Mn3, vitroplantas libres de patógenos. 


\section{Introduction}

Origanum vulgare, commonly known as Oregano, is an aromatic, dicotyledonous, perennial and branched plant [1]. It is found in a temperate to temperatewarm climate, can tolerate low temperatures, grows in loamy, permeable soils, with good drainage due to its high sensitivity to root asphyxia [2]. Its propagation can be carried out by means of the seed (heterogeneous population) and by division of plants (cuttings), normally the oregano is multiplied by means of cuttings and it is advisable to renew the plantation after 3 or 4 years.

The antimicrobial potential found in the essential oils of the genus Origanum present activity against Gram-negative bacteria (Salmonella typhimurium, Escherichia coli, etc.) and Gram-positive bacteria (Listeria monocytogenes, Bacillus subtilis, etc.) in addition to their antifungal capacity against Candida albicans, Aspergillus niger, etc. Phenols, carvacrol and thymol have the highest levels of activity against Gram-negative microorganisms, with thymol being the most active. Oleoresins are homogeneous mixtures of resin and essential oils, the latter containing volatile odoriferous principles. Some of the advantages of oleoresins over raw vegetables are that they are uniform in their characteristics, have a high purity and are economically profitable [3].

The technique of tissue culture consists essentially of carrying out an aseptic isolation of a portion of the plant called explante (e.g.: protoplast, cell, tissue, organ), in a medium of defined chemical keeping the cultures free of microbial contamination. The breadth of the definition of in vitro plant tissue cultures and the many different objectives pursued can be summarized as follows: 1. Basic studies of physiology, genetics, biochemistry and related sciences; 2. Bioconservation and production of useful compounds; 3 . Increase in genetic variability; 4. Obtaining pathogen-free plants; 5. Plant propagation and 6. Conservation and exchange of germplasm [4].

\section{Materials and methods}

Phase 1 Select the process of disinfection of Oregano explants in order to propagate seedlings aseptically

- Selection of the explant and mother plant: we worked with seeds of Origanum vulgare, from plants sown in the facilities of Playón Santander's SENA, which had a high content of thymol and carvacrol, important compounds for obtaining high quality essential oils.

- Explant disinfection: Three disinfection treatments were used, which differ in concentration, type of disinfectant agent and exposure times. Table I shows the established treatments.

In the three treatments $70 \%$ alcohol was applied, each one had three types of disinfectants, in which different variables were evaluated, taking into account possible negative effects on the explants.

\begin{tabular}{|c|c|c|c|c|}
\hline \multicolumn{2}{|c}{ Table I. Disinfection protocols applied to explants } \\
\hline Trat Treatments & $\begin{array}{c}\text { Type of hypochlorite } \\
(\%)\end{array}$ & Surfactante & $\begin{array}{c}\text { Disinfect } \\
\text { ant }\end{array}$ & $\begin{array}{c}\text { Time of } \\
\text { inmersion } \\
\text { (min) }\end{array}$ \\
\hline T1 & Sodium hypochlorite 1,5 & -- & $\begin{array}{c}\text { Povidona } \\
\text { yodada }\end{array}$ & 5 \\
\hline T2 & Sodium hypochlorite 1,5 & $\begin{array}{c}\text { Polisorbato } \\
80\end{array}$ & -- & 4 \\
\hline T3 & Hypochlorite Calcium 1 & -- & $\begin{array}{c}\text { Povidona } \\
\text { yodada }\end{array}$ & 3 \\
\hline
\end{tabular}

composition, artificially providing it with the appropriate physical and chemical conditions for the cells to express their intrinsic or induced potential,
In order to select the best treatment, three measurement variables were stipulated (Table II). 
Table II. Variables for disinfection measurement

\begin{tabular}{|c|c|c|}
\hline \multicolumn{2}{|c|}{ Disinfection variables } \\
\hline $\begin{array}{c}\text { Percentage of prosperous explants } \\
(\% \mathrm{EP})\end{array}$ & $\begin{array}{c}\text { Percentage of oxidized explants } \\
(\% \mathrm{EO})\end{array}$ & $\begin{array}{c}\text { Percentage of oxidized explants } \\
(\% \mathrm{EC})\end{array}$ \\
\hline$\% E P=\frac{\text { \#Prosperous Explantations }}{\# \text { Total Explantries }} * 100$ & $\% E O=\frac{\text { \#0xidized Explants }}{\text { \#Total Explantries }} * 100$ & $\%$ EC $=\frac{\text { \#Contaminated Explantations }}{\text { \#Total Explantries }} * 100$ \\
\hline
\end{tabular}

Source: [5]

\section{Phase 2 Develop the establishment phase of selected oregano plant material (Origanum vulgare) using modified Murashige \& Skoog basal medium}

Five culture media were formulated from the basal medium MS (Murashige and Skoog) which varied in the content of hormones, vitamins and activated carbon. The explants were sown and incubated at a temperature of $18{ }^{\circ} \mathrm{C}$, with a relative humidity of $65 \%$ and a photoperiod of 16 light hours. To determine the most suitable medium, measuring variables such as germination time and percentage of sprouted seeds were established.

Table III. Ms media content in the establishment phase
\begin{tabular}{|c|c|c|}
\hline $\begin{array}{c}\text { Growing } \\
\text { medium }\end{array}$ & $\begin{array}{c}\text { Giberylin } \\
\text { AG3 (mL) }\end{array}$ & $\begin{array}{c}\text { Activated } \\
\text { carbon (g) }\end{array}$ \\
\hline Ms1 & 1,2 & 3,5 \\
\hline Ms2 & 1,5 & 4,0 \\
\hline Ms3 & 0,5 & 0 \\
\hline Ms4 & 3 & 4,5 \\
\hline Ms5 & 5 & 2,5 \\
\hline
\end{tabular}

\section{Phase 3 Perform the multiplication phase of the explants of Oregano using modified basal medium MS (Murashige \& Skoog)}

The nodal segments and apical buds of the seedling were used. Cuttings of $0.5 \mathrm{~cm}$ between knots were made and then sowed in three culture media formulated for this phase (Mn 1, Mn 2 and Mn3).

The culture media were evaluated using five variables such as stem length, stem diameter, number of leaves, number of knots and number of branches.
Table IV. Ms media content in the multiplication phase

\begin{tabular}{|c|c|c|}
\hline $\begin{array}{c}\text { Growing } \\
\text { medium }\end{array}$ & $\begin{array}{c}\text { Auxina (ANA) } \\
(\mathbf{m L})\end{array}$ & $\begin{array}{c}\text { Cytokinin } \\
\text { (BAP) (mL) }\end{array}$ \\
\hline $\mathrm{Mn} 1$ & $0,5 \mathrm{ml}$ & $2,0 \mathrm{ml}$ \\
\hline $\mathrm{Mn} 2$ & $\mathrm{O}, 2 \mathrm{ml}$ & $2,0 \mathrm{ml}$ \\
\hline $\mathrm{Mn} 3$ & $2,0 \mathrm{ml}$ & $2,0 \mathrm{ml}$ \\
\hline
\end{tabular}

\section{Statistical analysis}

Each treatment was carried out in triplicate, with a total of 15 explants for each treatment, a subsequent statistical analysis will be carried out on the variants measured by means of an ANOVA.

\section{Results and discussion}

\section{Phase 1.}

In each of the treatments there were no significant differences due to the fact that the p-value was 0.2178 . However, it can be inferred that the most favourable data in the three treatments corresponded to treatment one (T1) (Povidone iodine, alcohol at 70\% and sodium hypochlorite at $1.5 \%$ during five minutes of immersion) with a contamination percentage of $0 \%$; followed by treatment three (T3) (Povidone iodine, $70 \%$ alcohol and 1\% calcium hypochlorite during three minutes of immersion), obtaining $6.6 \%$ contamination and finally treatment two (T2) (Polysorbate 80, 70\% alcohol and 1.5\% sodium hypochlorite during four minutes of immersion), which had the highest value in contamination, $20 \%$. (Table V)

In the contaminated explants, the fungus found in the highest percentage was the genus Penicillium with $60 \%$, followed by Aspergillus with $30 \%$ and Cladosporium with $10 \%$.

Table V. Evaluation of disinfection treatments

\begin{tabular}{|c|c|c|c|}
\hline Treatment & Prosperous (\%) & Contaminated (\%) & Oxidized (\%) \\
\hline T1 & 100 & 0 & 0 \\
\hline T2 & 80 & 20 & 0 \\
\hline T3 & 93,3 & 6,6 & 0 \\
\hline
\end{tabular}


The fungi found as contaminants of the culture media in the phase were reported in Table VI.

Table VI. Fungal contaminants in the culture media of the establishment phase of Origanum vulgare

\begin{tabular}{|c|l|l|}
\hline \multicolumn{1}{|c|}{ Gender } & Macroscopic & Microscopic \\
\hline $\begin{array}{c}\text { Cladosporium } \\
\text { spp. }\end{array}$ & & \\
\hline & & \\
Aspergillus spp. & & \\
\hline & & \\
\hline & & \\
\hline
\end{tabular}

From these results, it can be seen that the treatments containing povidone-iodine obtained the best results, due to its mechanism of bactericidal and fungicidal action, as it gradually releases the iodine it contains [6]. Likewise, it is deduced that treatment number two, which contains polysorbate 80 , is used as a humectant, increasing the water retention capacity, which indicates the high humidity of the explant, resulting in the presence of fungi [4]. The treatments evaluated in the oxidation variable obtained $0 \%$ oxidized phenolic substances, in addition to other substances that intervene causing cellular damage and produce seeds.

\section{Phase 2.}

The culture media used in this phase present a statistically significant difference with a p-value of 0,0001 . It can be seen that the growing medium Ms4 has the highest seedling emergence rate after eight days of sowing (Figure 1), the second medium with the highest amount of germination was the medium. Ms2, with a $66.7 \%$ and Ms3 obtained a deficient yield with $0 \%$ germination, with these results and observing the differences in the use of $\mathrm{AG}_{3}$ and activated carbon from the five media evaluated, the Ms3 media does not contain activated carbon and the addition of $\mathrm{AG}_{3}$ was in low quantity, however, was not the medium with the highest content of gibberylin $\mathrm{AG}_{3}$ the one that obtained better results, for this reason we can deduce that the seeds of Origanum vulgare, germinate in a medium that contains activated carbon and a range of $1200-$ $3000 \mu \mathrm{lde} \mathrm{AG}_{3}$.

The effect that the activated carbon has on the explants is representative, according to what was exposed by [8], explains that the dose of activated

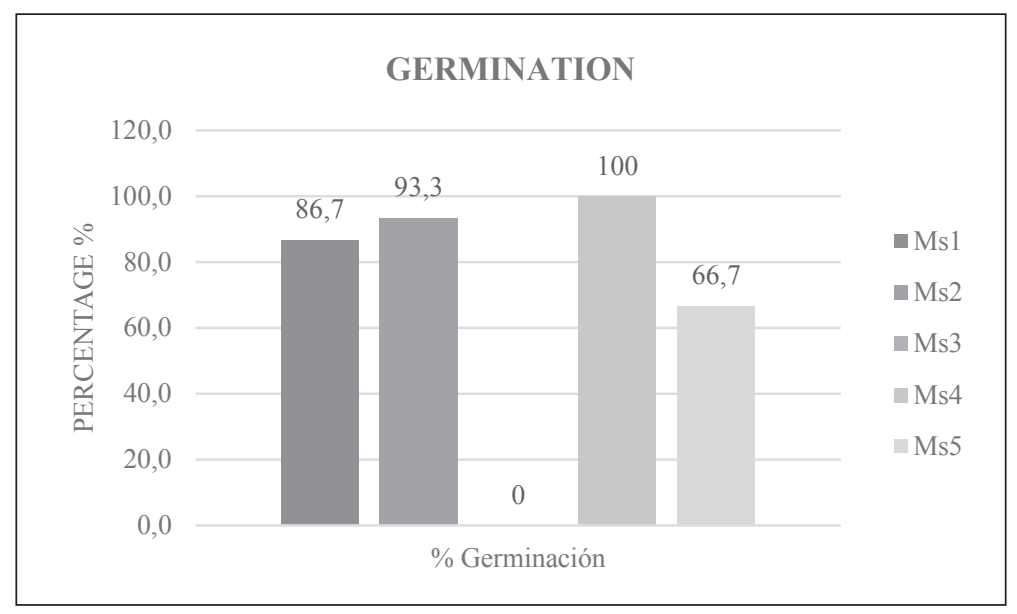

Figure 1. Graph of the establishment phase

oxidation, as described by [7], the application of disinfection and rinses with sterile distilled water, as a pre-treatment to explants, are very useful, because they act in the removal of both disinfectants and carbon can vary from $0,5-5,0 \mathrm{~g} / \mathrm{L}$, and it is in this range where there is stimulation of the processes of morphogenic development, the Ms3 medium was the only one that was not added activated carbon, 
thus deducing that so much the little volume applied to the activated carbon, that it was not possible to use the activated carbon. $\mathrm{AG}_{3}$ as the non-addition of activated carbon in the culture medium would cause the non-emergence of the radicle, nor the development of the plant. Because germination is linked to the use of $\mathrm{AG}_{3}$, that to high concentrations the seeds can remain in state of dormancy, for this reason it is possible that the medium Ms5 is with a very low percentage of germination.

\section{Phase 3. Stem length}

In the length of the stem it can be seen that the middle Mn3 had the largest size in the shoots with an average of $7.6 \mathrm{~cm}$, the middle $\mathrm{Mn} 1$ and $\mathrm{Mn} 2$, showed an average of $5.5 \mathrm{~cm}$ of $2 \mathrm{~cm}$ stem length respectively (Figure 2).

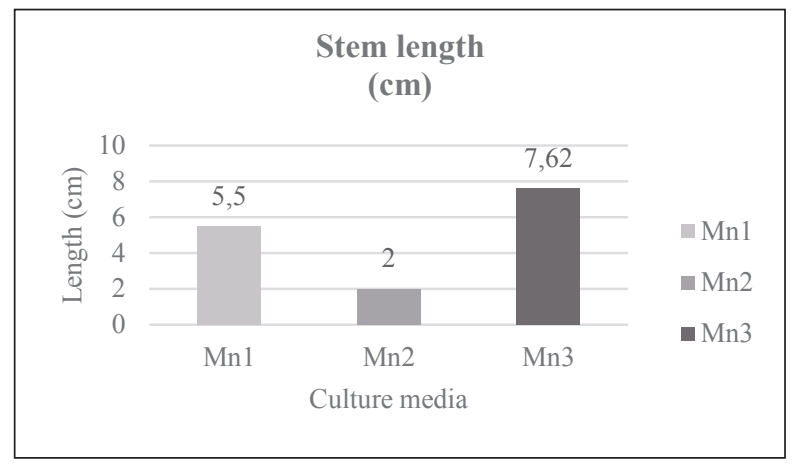

Figure 2. Graph of the multiplication phase of the stem length variable in centimetres

\section{Stem diameter}

The medium that provides the plants with the largest diameter of the stem is the Mn3 with an average of $1 \mathrm{~cm}$, the plants of the means Mn1 and Mn2 have an average of 0.6 and $0.4 \mathrm{~cm}$ respectively, as shown in Figure 3.

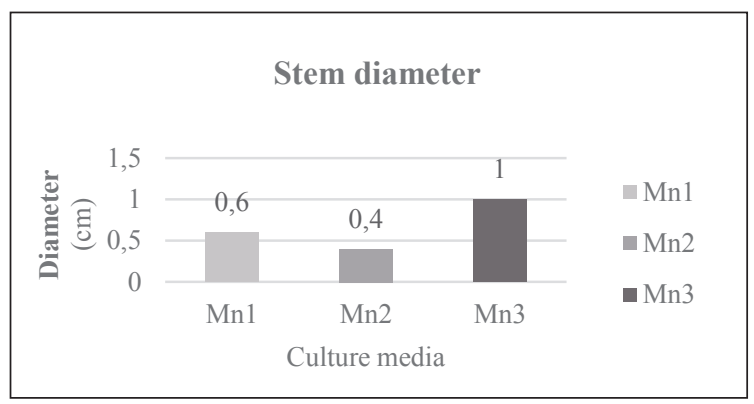

Figure 3. Graph of the multiplication phase of the stem diameter variable

\section{Number of sheets}

The medium Mn3 obtained the highest number of leaves, with an average of 11 leaves per plant, the cultivation media $\mathrm{Mn} 1$ and $\mathrm{Mn}$ 2, have favorable values, because the average is 8 and 7 leaves respectively, to relate the variables of this phase and take into account the length and diameter of the stem, it can be inferred that the medium Mn3 is the one that provides the plant with better phenotypic characteristics (Figure4).

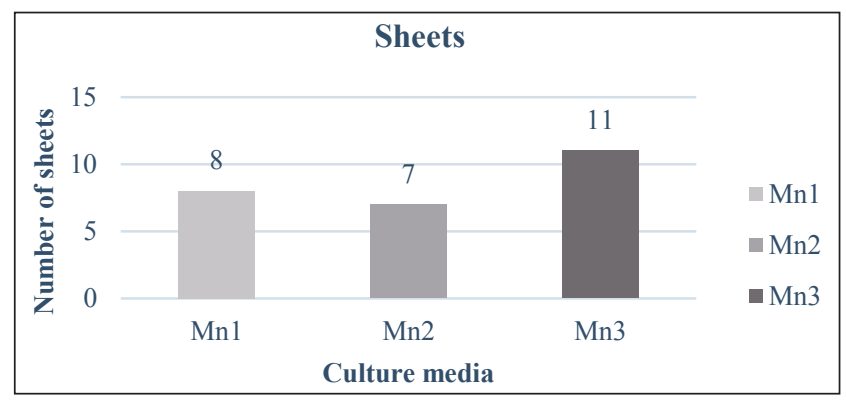

Figure 4. Graph of the multiplication phase of the variable number of leaves

\section{Number of knots}

The explants sown in the middle Mn3 have an average of 5 leaves, in relation to the means Mn1 and Mn2 with an average of 3 and 2 leaves respectively (Figure 5).

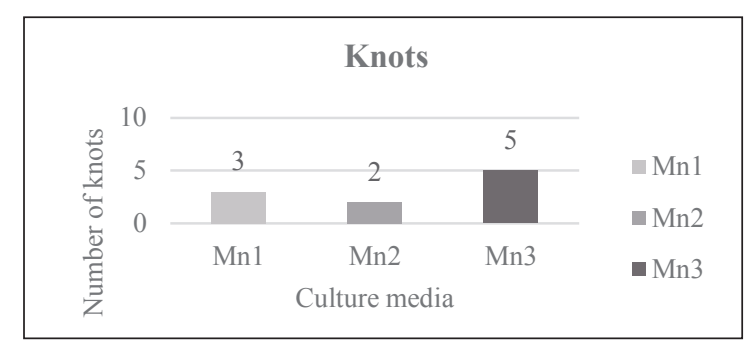

Figure 5. Graph of the multiplication phase of the number of knots variable

\section{Number of ramifications}

In the data for this variable, the culture mediums Mn1 and Mn2 allowed the favourable growth of a significant number of branches (three), compared to the medium Mn3 with 1 branch (Figure6). 


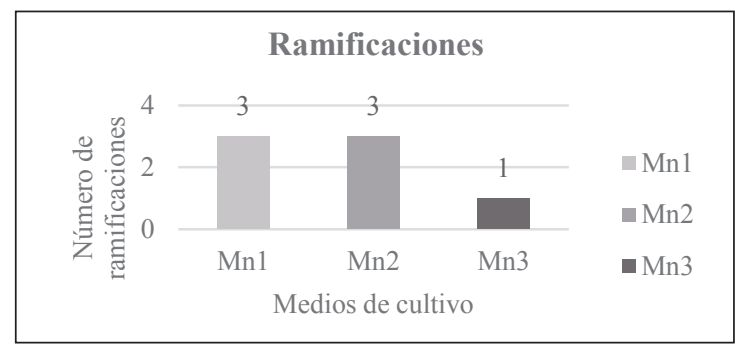

Figure 6. Graph of the multiplication phase of the variable number of branches

In the stage of multiplication of cuttings, is obtained as a result of a ratio of 1:20 with two repiques made, phenotypically the plants have the best characteristics found among the three media of cultivation, with an average height of $7.6 \mathrm{~cm}$, a number of leaves average of 11, number of knots average of 5 and a single branching, these characteristics exposed are those that provides the plant the medium Mn3.

The results obtained in this research are similar to those recorded by [9], who indicate that a hormonal balance should be made between auxins and cytokinins that benefit the sprouting of nodal segments of oregano, as it was made in this investigation the balances were for $\mathrm{Mn} 1,0,5 \mathrm{ml}$ of ANA and $2 \mathrm{ml}$ of BAP and for Mn2, 0,2 of ANA and $1,5 \mathrm{ml}$ of BAP respectively and $\mathrm{Mn} 3$ with a content of ANA of $2 \mathrm{ml} / \mathrm{L}$ and BAP of $2 \mathrm{ml} / \mathrm{L}$. In addition to that recorded by [5], where the importance of the addition of BAP, Kinetin and AG3 for obtaining maximum regeneration values is highlighted, the efficiency of the culture medium is also highlighted when BAP is added in a higher proportion than ANA.

Records were found of possible problems, including vitrification and malformations, as explained [10]. Currently, after several trials that have been developed for some aromatic species, including oregano, multiplication by in vitro cultures. The development of this new technique initially stumbled upon the appearance of physiological malformations in the regeneration stages of cloned plants from tissue cultures. However, the plants that were cultivated in this research in this phase, no problem was found, this was due to the environmental conditions offered to the explant for growth were the most optimal, starting with the photoperiod of 16 light hours at a temperature of $18{ }^{\circ} \mathrm{C}$ and relative humidity of $65 \%$.

\section{Conclusions}

he disinfection treatment that showed the best effect on the explants was number 1, which had Povidona iodada, 70\% alcohol and sodium hypochlorite at $1.5 \%$ during five minutes of immersion, each has mechanisms of action that helps the elimination of bacteria and fungi.

In the establishment phase, the medium that obtained the greatest amount of germinated seeds was Ms4, which has $100 \%$ germination in only eight days.

In the multiplication phase, the MS culture medium that was standardized and gave the plant good characteristics, such as height, number of leaves, number of knots, etc., is Mn3.

We obtained 20 seedlings from each node and apical bud, showing that the in vitro cultivation technique is efficient in the massive propagation of plants.

\section{References}

[1] E. García-Pérez, F.F. Castro-Álvarez, J.A. Gutiérrez-Uribe y S. García-Lara, "Revisión de la producción, composición fitoquímica y propiedades nutracéuticas del orégano mexicano", Revista Mexicana de Ciencias Agricolas, vol. 3, no. 2, pp. 339-353, 2012.

[2] M. E. Torrenegra-Alarcón, "Evaluación de la actividad antioxidante del aceite esencial foliar extraido de especies de Orégano(Origanum vulgare), Orégano "Borde Blanco" (Origanum vulgare ssp) y Oreganito(Lippia alba mill) cultivado en la zona norte del departamento de Bolívar (Col.)", Cartagena de Indias, 2014.

[3] M. A. Salamanca García y M. Sánchez Bermúdez, "Extracción y caracterización de la oleorresina del orégano( origanum vulgare)", Pereira, 2009.

[4] W.M. Rocay L.A. Mroginski, "Estabelcimiento de un laboratorio para el cultivo de tejidos vegtales", de Cultivo de Tejidos en la Agricultura, Fundamentos y Aplicaciones, Cali, Centro Internacional de Agricultura Tropical (CIAT), 1991, pp. 1-19. 
[5] G. Braun y U. Zuccari, "Aportes biotecnoloógicos al cultivo de orégano", 2014. [En línea].

[6] "YODOPOVIDONA 10\% SoluciónAntiséptico desinfectante". Bolivia.

[7] Á. Azofeifa Delgado, "Problemas de oxidación y oscurecimiento de explantes cultivados in vitro", Agronomía Mesoamericana, vol. 20, no. $1,2009$.

[8] J. A. Pedroza Manrique, "Efecto del carbón activado, ácido indolacético (AIA) y bencil amino purina (BAP) en el desarrollo de protocormos de Epidendrum elongatum Jacq bajo condiciones in vitro" Revista Colombiana de Biotecnología, vol. 11, no. 1, pp. 17-32, 2009.

[9] M. A. rojas Pérez, G. Montes Rivera, R. Silva Vásquez y B. Díaz Ramírez, "Respuesta al balance hormonal en segmentos nodales de orégano (Lippia berlandieri Schauer)", RESPYN, vol. Edición Especial, no. 1-2008, 2007.

[10] A. Cano Ortíz y C. Martínez Lombardo, "Cultivo de plantas medicinales en la provincia de Jaén", Boletín del instituto de estudios Giennenses, no. 200, pp. 195-230, 2009. 